\title{
Identifikasi Pola Spasial Kriminalitas Kota Berdasarkan Faktor Ekologi Kriminal Di Kabupaten Sidoarjo
}

\author{
Ramadhany Ashari dan Cahyono Susetyo \\ Departemen Perencanaan Wilayah dan Kota, Institut Teknologi Sepuluh Nopember (ITS) \\ e-mail: cahyono_s@urplan.its.ac.id
}

\begin{abstract}
Abstrak-Permasalah Kota-kota Indonesia yang berujung pada menurunnya kualitas lingkungan perkotaan. Permasalahan lingkungan, sosial, kependudukan, infrastruktur, lapangan kerja, dan lain sebagainya merupakan isu perkotaan yang seringkali bermunculan di ruang publik, baik dalam bentuk media ataupun diseminasi public. Tujuan dilakukan penelitian ini adalah untuk mengetahui Pola Spasial Kriminal Pencurian Berdasarkan Faktor Ekologi Kriminal di Kabupaten Sidoarjo sebagai perspektif teoritis kecenderungan lingkungan pembentuk tindak criminal. Untuk mencapai tujuan tersebut, maka perlu dicapai sasaran dalam penelitian ini berupa; Menganalisis faktor-faktor ekologi kriminal yang menentukan tingkat kriminalitas di Kabupaten Sidoarjo;Mengidentifikasi pola spasial kriminal pencurian di Kabupaten Sidoarjo; Mengidentifikasi korelasi antara pola spasial kriminal pencurian dengan faktor-faktor ekologi kriminal. Penelitian ini menggunakan teknik analisis dot density dan analisis korelasi. Dimana kedua analisis tersebut digunakan untuk mengetahui persebaran lokasi kriminalitas kota serta mengetahui besaran pengaruh kriminalitas suatu wilayah. Dari analisis yang telah dilakukan, didapatkan hasil akhir bahwa faktor-faktor yang berpengaruh dalam kriminalitas di Kabupaten Sidoarjo diantaranya adalah padatnya penduduk, permukiman, pengangguran, kawasan komersil. Berdasarkan hasil penelitian tipe Difusi Penampungan (Relocation diffusion), yang merupakan proses yang sama dengan persebaran keruangan dimana informasi atau material yang didifusikan meninggalkan daerah yang lama dan berpindah atau ditampung di daerah yang baru dan Faktor-faktor ekologi kriminal yang berkorelasi kuat sebagai faktor pembentuk kriminal pencurian di Kabupaten Sidoarjo adalah luas permukiman dan luas kawasan komersil Sedangkan populasi, kepadatan dan kemiskinan penduduk berkorelasi rendah sampai sedang.
\end{abstract}

Kata Kunci_Ekologi Kriminal, Kriminalitas Kota, Pola Spasial.

\section{PENDAHULUAN}

$\mathrm{M}$ ENURUT hasil penelitian yang dilakukan oleh Ikatan Ahli Perencana (IAP) yaitu Survey Most Livable City Index pada tahun 2011 dari, menjelaskan memasuki dekade kedua abad 21, kota-kota Indonesia mengalami berbagai persoalan yang berujung pada menurunnya kualitas lingkungan perkotaan. Permasalahan lingkungan, sosial, kependudukan, infrastruktur, lapangan kerja, dan lain sebagainya merupakan isu perkotaan yang seringkali bermunculan di ruang publik, baik dalam bentuk media ataupun diseminasi publik [1]. Faktor Ekonomi sebagai katalis dari kedua objek perencanaan tersebut telah menjadikan jumlah penduduk perkotaan secara global sudah lebih banyak dibandingkan dengan jumlah penduduk di kawasan pedesaan sejak tahun 2008. Salah satu dari 9 kriteria utama Survey Most Livable City tahun 2011 yang dilakukan Ikatan Ahli Perencana (IAP) adalah Aspek Keamanan, faktor ini menempati urutan ke-empat dari 5 aspek utama penentu tingkat kenyamanan kota dengan persentase 11,08\%, sedangkan faktor-faktor lain yaitu Aspek ekonomi (27,97\%), Aspek tata ruang $(19,66 \%)$, Aspek fasilitas pendidikan $(13,29 \%)$, Aspek kebersihan (10,80\%).

Mayoritas warga kota berpendapat bahwa tingkat kriminalitas merupakan permasalahan di kawasan perkotaan. Kota-kota yang dipersepsikan memiliki tingkat kriminalitas tinggi oleh warganya adalah Kota Makassar, Jayapura, Surabaya dskt dan Jakarta, sedangkan kota yang dipersepsikan memiliki tingkat kriminalitas rendah oleh warganya adalah Menado, Bandung dan Palangkaraya.

Dasar kajian penelitian menurut Pendekatan Ekologikal adalah ide analisis untuk sebuah kota, pertama kali diilhami oleh proses persaingan alami yang terjadi pada tumbuhan dan binatang. Ide ini mendorong pengembangan "Human Ecology" yang kemudian diartikannya sebagai suatu studi hubungan spatial dan temporal dari manusia yang dipengaruhi oleh kekuatan, selektif, distributif, dan akomodatif dari lingkungannya [2]. Hubungan tingkattingkat kejahatan perkotaan dan pola geografisnya yang sejak 1930 lebih dipopulerkan sebagai Teori Ekologi Kriminal (Crime Ecology). Teori Ekologi Kriminal mengkaji peran tempat (place) dalam membentuk tindak kriminalitas pencurian sesuai teori-teori spasial sebagai dampak disfungsi sosial dan dampak perkembangan pola spasial kekotaanya [3].

Kabupaten Sidoarjo sebagai sebuah kota yang berkembang pesat patut dijadikan sebagai objek studi ini. Kabupaten Sidoarjo berdasarkan data dari Badan Pusat Statistik (BPS), merupakan kota administratif kedua terbesar di Propinsi Jawa Timur berdasarkan tingkat populasi yaitu sebesar 2.223.002 jiwa atau mengalami kenaikan 49,93 persen dibandingkan dengan tahun 2015. Jumlah penduduk terbesar di Kecamatan Waru, diikuti Kecamatan Taman dan Kecamatan Sidoarjo.

Data kepadatan penduduk Kabupaten Sidoarjo adalah $3.141,11 \mathrm{jiwa} / \mathrm{Km} 2$ dengan tingkat pertumbuhan $1.63 \%$ per tahun. Fakta di atas diikuti dengan Angka kriminalitas di Kabupaten Sidoarjo yang menunjukkan peningkatan setiap tahunnya, setidaknya dari data Kepolisian Resta Kabupaten Sidoarjo menyebutkan terjadinya peningkatan angka kriminalitas di tahun 2016 naik tiga persen dibanding pada tahun 2015 yang dilansir Media Berita Jatim akhir 2016. Selain itu dalam Kabupaten Sidoarjo Dalam Angka 2017 menyebutkan bahwa Jumlah kriminalitas yang dilaporkan di 
Tabel 1.

Variabel Penelitian

\begin{tabular}{|c|c|}
\hline Aspek & Variabel \\
\hline Tingkat-tingkat kejahatan & $\begin{array}{l}\text { - Angka Kriminal dan Pencurian tiap kecamatan di Kabupaten Sidoarjo } \\
\text { - Persebaran Angka Kriminal tiap kecamatan di Kabupaten Sidoarjo }\end{array}$ \\
\hline Kepadatan Penduduk & $\begin{array}{l}\text { - Jumlah Kepadatan Penduduk tiap kecamatan di Kabupaten Sidoarjo } \\
\text { - Persebaran Jumlah Kepadatan Penduduk tiap kecamatan di Kabupaten Sidoarjo }\end{array}$ \\
\hline Kemiskinan & $\begin{array}{l}\text { - Keamanan Lingkungan Jumlah Penduduk Miskin tiap kecamatan di Kabupaten Sidoarjo } \\
\text { - Persebaran Penduduk Miskin tiap kecamatan di Kabupaten Sidoarjo }\end{array}$ \\
\hline $\begin{array}{l}\text { Penggunaan Campuran Permukiman dan } \\
\text { Komersial }\end{array}$ & $\begin{array}{l}\text { - Luas wilayah Permukiman tiap kecamatan di Kabupaten Sidoarjo } \\
\text { - Persebaran luas wilayah Permukiman tiap kecamatan di Kabupaten Sidoarjo } \\
\text { - Luas wilayah Komersial tiap kecamatan di Kabupaten Sidoarjo } \\
\text { - Persebaran luas wilayah Komersial tiap kecamatan di Kabupaten Sidoarjo }\end{array}$ \\
\hline Dilapidasi /Kekumuhan & $\begin{array}{l}\text { - Luas wilayah Kumuh tiap kecamatan di Kabupaten Sidoarjo } \\
\text { - Persebaran luas wilayah Kumuh tiap kecamatan di Kabupaten Sidoarjo }\end{array}$ \\
\hline $\begin{array}{l}\text { Adanya pelaku yang termotivasi } \\
\text { (seperti remaja menganggur) }\end{array}$ & $\begin{array}{l}\text { - Jumlah remaja tiap kecamatan di Kabupaten Sidoarjo } \\
\text { - Persebaran remaja tiap kecamatan di Kabupaten Sidoarjo } \\
\text { - Jumlah Pengangguran tiap kecamatan di Kabupaten Sidoarjo } \\
\text { - Persebaran Pengangguran tiap kecamatan di Kabupaten Sidoarjo }\end{array}$ \\
\hline Struktur Kota & $\begin{array}{l}\text { - Struktur Kabupaten Sidoarjo berdasarkan RTRW Kabupaten Sidoarjo 2009-2029 dalam } \\
\text { Perda No. } 6 \text { Tahun } 2009\end{array}$ \\
\hline
\end{tabular}

POLRES Kabupaten Sidoarjo sebanyak 2.144 kasus dan selesai sejumlah 1.714 kasus. Secara total jumlah kriminalitas selama tahun 2016 lebih tinggi dibanding tahun sebelumnya. Jenis tindak kriminalitas berdasarkan Badan Pusat Statistik yang paling tinggi adalah pencurian meliputi Curas, Curat, Curanmor dan Curi Biasa dengan 64,87\% dari total 2.144 kasus (Kasus Pidana). Fenomena tingginya pelaporan kasus pencurian di Kabupaten Sidoarjo ini menjadi menarik untuk diteliti pola spasialnya dari perspektif teoritis kecenderungan lingkungan pembentuk tindak kriminal dan mengkaji sebarannya sesuai struktur ruang kota yang telah ada. Hal ini dilakukan untuk mendapatkan sebuah gambaran arah persebaran wilayah kasus pencurian di Kabupaten Sidoarjo berdasarkan dampak dinamika ruang spasial kota dan sosial masyarakat kota.

Dengan teori dan fakta serta fenomena di atas, maka studi ini dilakukan untuk mengkaji pola spasial kriminal pencurian dan korelasi faktor ekologi kriminal di Kabupaten Sidoarjo yang diharapkan dapat memberikan gambaran tingkat kriminalitas secara spasial di masyarakat sebagai suatu dampak dari perkembangan kota secara fisik dan sosial sehingga menjadi bahan pertimbangan dalam menentukkan kebijakan perencanaan preventif dari aspek penataan ruang khususnya bagi tindak kriminalitas pencurian untuk Kabupaten Sidoarjo dengan tujuan tercapainya sebuah kondisi kota yang nyaman bagi penghuninya.

\section{METODE PENELITIAN}

\section{A. Jenis dan Pendekatan Penelitian}

Penelitian ini merupakan gabungan penelitian Korelasional dan kausal-komparatif. Menurut Suryabrata (1983), tujuan penelitian korelasional adalah untuk mendeteksi sejauh mana variasi-variasi pada suatu faktor berkaitan dengan variasi-variasi pada satu atau lebih faktor lain berdasarkan pada koefisien korelasi. Studi semacam ini memungkinkan pengukuran beberapa variabel dan saling hubungannya secara serentak dalam keadaan realistiknya. Adapun tujuan penelitian kausal-komparatif adalah untuk menyelidiki kemungkinan hubungan sebab-akibat dengan cara berdasar atas pengamatan terhadap akibat yang ada mencari kembali faktor yang menjadi penyebab melalui data tertentu.

\section{B. Variabel Penelitian}

Adapun variabel yang digunakan dalam penelitian ini adalah seperti pada Tabel 1 .

\section{Metode Pengumpulan Data}

Pengumpulan data dan informasi dalam penelitian ini dilakukan dengan metode Survei sekunder. Pendekatan ini menggunakan data-data yang telah ada, selanjutnya dilakukan proses analisa dan interpretasi terhadap data-data tersebut sesuai dengan tujuan penelitian. Data-data skala kota yang dikumpulkan sesuai unit pengamatan penelitian yaitu mencakup 5 Kecamatan (Kecamatan Waru, Kecamatan Gedangan, Kecamatan Buduran, Kecamatan Sidoarjo dan Kecamatan Candi) di Kabupaten Sidoarjo. Data sekunder dapat diklasifikasikan berdasarkan sumber, yaitu data internal dan data eksternal.

\section{Populasi dan Sampling}

Penelitian ini menggunakan unit pengamatan pada 5 kecamatan di Kabupaten Sidoarjo dengan maksud memberikan gambaran umum distribusi dan faktor-faktor pembentuk area kriminal pencurianitas di Kabupaten Sidoarjo. Unit amatan dalam penelitian ini adalah sebuah bentuk populasi sebagai wilayah generalisasi yang terdiri atas; obyek/subyek yang mempunyai kuantitas dan karakteristik tertentu yang ditetapkan oleh peneliti untuk dipelajari dan kemudian ditarik kesimpulannya [4].

\section{E. Teknik Analisis Data}

Kegiatan analisis ini merupakan tindak lanjut dari kegiatan pengumpulan data-data penelitian. Metode analisis yang digunakan adalah uji statistik dan Geographic Information System (GIS). Analisis dimulai dengan menguji validitas data penelitian yang akan digunakan diukur oleh instrumen statistik dalam uji hipotesis penelitian, kemudian analisis secara spasial dengan GIS akan memberikan gambaran secara lebih lengkap terhadap hasil penelitian. 


\section{1) Statistik Deskriptif}

Statistika deskriptif adalah tehnik yang digunakan untuk mensarikan data dan menampilkannya dalam bentuk yang dapat dimengerti oleh setiap orang [4]. Hal ini melibatkan proses kuantifikasi dari penemuan suatu fenomena dalam statistik sederhana, seperti rata-rata, dihitung dan ditampilkan dalam bentuk tabel dan grafik. Statistika deskriptif dapat memberikan pengetahuan yang signifikan pada kejadian fenomena yang belum dikenal dan mendeteksi keterkaitan yang ada di dalamnya. Statistika deskriptif hanya memberikan informasi mengenai data yang dipunyai dan sama sekali tidak menarik inferensia atau kesimpulan apapun tentang gugus induknya yang lebih besar.

\section{2) Statistik Parametrik Korelasi Product Moment}

Statistik parametrik adalah bagian dari statistik inferensial yang digunakan untuk menganalisis data interval dan rasio yang diambil kesimpulan bagi populasi dari populasi yang berdistribusi normal. Statistik parametrik ini digunakan karena tujuan penelitian adalah mencari asosiasi atau hubungan antara variabel pada sumber data interval atau rasio; seperti data-data yang akan dipeoleh dalam penelitian ini. Teknik korelasi dapat berperan sebagai statistik inferehensial [4]. Rangkaian teknik analisis ini meliputi uji korelasi menggunakan pearson product moment. Korelasi Analisis data yang digunakan untuk melihat hubungan antara Angka kriminal pencurian dan faktor-faktor ekologi di atas adalah dengan menggunakan korelasi product moment dari Karl Pearson. Kegunaan dari korelasi ini adalah yaitu untuk menguji dua signifikansi dua variabel, mengetahui kuat lemah hubungan, dan mengetahui besar retribusi.

\section{3) Crime Mapping dengan GIS}

Proses pemetaan yang digunakan dalam penelitian ini disebut crime mapping dengan menggunakan pendekatan GIS lewat Software Arcgis 10.4.2 buatan produsen ESRI. Analisis GIS yang digunakan dalam penelitian ini adalah Overlay dan Dot Density yang menghasilkan peta yang mengkomunikasikan berapa banyak sesuatu data dengan menggambar fitur menggunakan ukuran kuantitatif. Langkah ini mungkin untuk menghitung count; rasio, seperti persentase, atau pangkat, seperti tinggi, sedang, atau rendah. Metode pemetaan kerapatan titik yang dapat menunjukkan jumlah atribut di dalam suatu daerah. Setiap titik mewakili sejumlah tertentu fitur, misalnya, 1.000 orang atau 10 perampokan di dalam suatu daerah.

Peta kepadatan titik menunjukkan kepadatan grafis daripada menunjukkan nilai kepadatan. Titik- titik yang didistribusikan secara acak di dalam setiap daerah, mereka tidak mewakili lokasi fitur yang sebenarnya. Semakin dekat bersama titik-titik, semakin tinggi kepadatan fitur di daerah itu.

\section{HASIL DAN DISKUSI}

\section{A. Gambaran Umum Kawasan Penelitian}

Kabupaten Sidoarjo merupakan kabupaten yang dihimpit oleh dua sungai yaitu Sungai Porong dan Sungai Surabaya sehingga terkenal sebagai kota Delta. Wilayah administrasi Kecamatan Waru Kabupaten Sidoarjo terdiri atas wilayah daratan dan wilayah lautan. Luas wilayah daratan adalah sebesar 714,245 Km2. Secara administratif Kabupaten
Sidoarjo termasuk dalam provinsi Jawa Timur dengan batas administrasi sebagai berikut :

Sebelah Utara : Kota Surabaya

Sebelah Timur : Selat Madura

Sebelah Selatan : Kecamatan Gedangan

Sebelah Barat : Kecamatan Taman

Perkembangan jumlah penduduk

Dari hasil registrasi penduduk, jumlah penduduk Kabupaten Sidoarjo pada akhir tahun 2016 sebesar 1.480.578 jiwa, terjadi kenaikan 32.185 jiwa atau sebesar 2,66 persen dari akhir tahun 2015 sebesar 1.448.393 jiwa.

Penduduk Kabupaten Sidoarjo ditinjau dari kelompok umurnya menunjukkan bahwa, sebagian besar berada pada kelompok umur $25-29$ tahun yaitu 160.892 jiwa. Kelompok umur ini termasuk kelompok usia produktif. Sedangkan penduduk usia non produktif adalah 446.583 jiwa, terdiri dari kelompok umur 0-14 th sebesar 391.540 jiwa dan kelompok umur diatas 64 th sebanyak 55.043 jiwa.

Kepadatan penduduk Dengan luas wilayah sebesar 714,24 $\mathrm{Km} 2$, dan dengan jumlah penduduk sebesar 1.480 .578 jiwa, maka kepadatan penduduk Kabupaten Sidoarjo adalah 21 jiwa/ Ha. Karena persebaran penduduk tiap-tiap Kecamatan berbeda, maka terdapat Kecamatan yang memiliki kepadatan penduduk yang tinggi, dan sebaliknya terdapat Kecamatan dengan kepadatan penduduk yang rendah. Kecamatan dengan tingkat kepadatan penduduk yang tertinggi adalah Kecamatan Waru, Taman, dan gedangan. Sedangkan Kecamatan dengan tingkat kepadatan yang rendah adalah Kecamatan Jabon dan Sedati.

Berdasarkan data yang diperoleh dari Dinas Tenaga Kerja dapat diketahui bahwa jumlah pencari kerja di Kabupaten Sidoarjo tahun 2016 adalah sebanyak 8.812 orang. Terjadi penurunan jika dibandingkan tahun 2015 sebesar 25.556 orang atau turun 65,52 persen.

Mata pencaharian terbesar penduduk Kabupaten Sidoarjo adalah sebagai pekerja swasta yaitu 313.658 jiwa atau sekitar $46,58 \%$ dari seluruh tenaga kerja yang terserap dalam kegiatan ekonomi. Selanjutnya, mata pencaharian wiraswasta dan buruh tani menempati urutan kedua dan ketiga, masingmasing sebesar 90.273 dan 75.401 jiwa. Kecamatan dengan jumlah penduduk bekerja lebih dari 50 ribu jiwa adalah Kecamatan Candi, Waru, Krian, dan Taman, yaitu masingmasing sebesar 87.966, 74.836, 62.703 dan 58.884 jiwa. Sedangkan Kecamatan dengan jumlah penduduk bekerja kurang dari 20 ribu jiwa adalah Kecamatan Sukodono dan Krembung.

Penggunaan lahan di Kabupaten Sidoarjo dengan luas $71.424,25 \mathrm{Ha}$, terdiri atas penggunaan lahan untuk kawasan lindung dan penggunaan lahan untuk kawasan budidaya. Penggunaan lahan untuk kawasan lindung meliputi penggunaan lahan untuk sempadan pantai, sempadan sungai, cagar alam, taman wisata alam, cagar budaya, dan kawasan hutan bakau. Sedangkan penggunaan lahan untuk budidaya meliputi permukiman, pertanian, pertambangan, industri, pariwisata dan konservasi bangunan sejarah.

Penggunaan lahan untuk kawasan lindung berupa sempadan sungai terdapat pada Sungai Magetan, Sungai Porong, Kali Butung, Sungai Brantas, dan Sungai Mas. Sedangkan penggunaan lahan untuk perlindungan hutan bakau terdapat di pantai Timur Sidoarjo, dengan luas $1.038,25 \mathrm{Ha}$. 


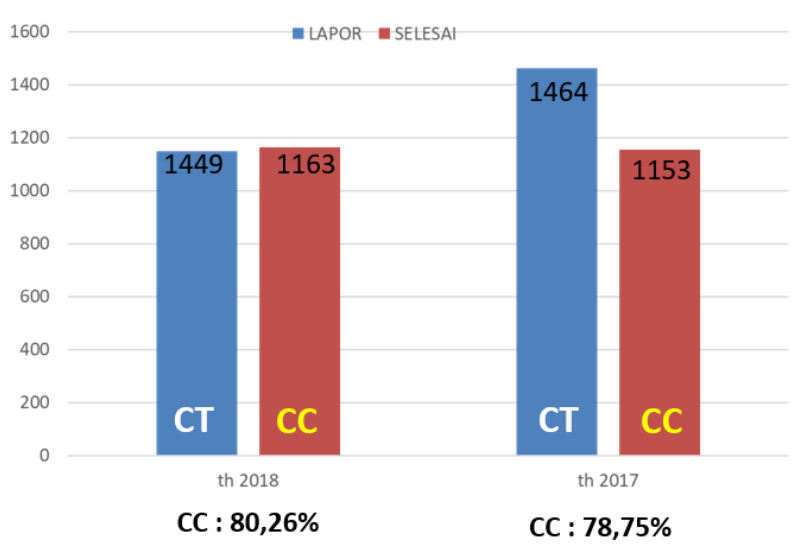

Gambar 1. Tren Tingkat Kriminalitas pada Wilayah Penelitian

Penggunaan lahan lainnnya yaitu cagar budaya berupa Situs Purbakala candi yang ada di kecamatan Porong, Wonoayu dan Kecamatan Sedati sebanyak 5 buah dengan luas kurang lebih 7ha, serta cagar budaya makam Dewi Sekardadu di Desa Kepetingan, Kecamatan Buduran. Penggunaan lahan yang dominan di Kabupaten Sidoarjo merupakan kawasan budidaya, yaitu mencapai $67.384,55 \mathrm{Ha}$, atau sekitar $94,34 \%$ dari luas wilayah keseluruhan, dengan klasifikasi penggunaan lahan berupa permukiman, industri, pertambangan, pertanian, perikanan, tanah kosong, jalan dan sungai/saluran. Untuk mengetahui lebih jelas penggunaan lahan budidaya di Kabupaten Sidoarjo, dapat dilihat pada tabel di bawah ini.

\section{B. Analisis Distribusi Data dan Pola Spasial Kasus Kriminal dan Pencurian di Wilayah Penelitian}

Hasil analisis pada bagian ini menyampaikan gambaran tentang perkembangan kriminalitas umum dan pencurian secara khusus dalam bentuk pola distribusi data maupun pola spasialnya di Wilayah Penelitian. Pola distribusi data memberikan identifikasi trend data baik penurunan dan kenaikannya dalam setiap kecamatan Wilayah Penelitian. Analisis spasial memberikan identifikasi persebaran kepadatan pencurian dalam kaitannya dengan struktur ruang kota.

Seperti yang terdapat pada Gambar 1, bahwa tren kriminalitas pada tahun 2018 menurun dibandingkan dengan tahun 2017. Namun penurunan yang terjadi tidak signifikan. Belum lagi kasus-kasus kriminalitas yang tidak terlaporkan. Namun pada grafik diatas tingkat penyelesaian atas kasus kriminalitas lebih tinggi daripada penyelesaian yang terjadi pada tahun 2017. Hal tersebut harus menjadi perhaian dalam mencegah kasus kriminalitas terjadi [5].

Analisis yang dapat diperoleh dari distribusi data ini adalah bahwa angka pencurian di Wilayah Penelitian cenderung bertambah seiring meningkatnya tingkat kriminal. Wilayah Kecamatan Waru mendominasi pada awal 2017. Selanjutnya Kecamatan Gedangan dan Kecamatan Sidoarjo Kota mendominasi dalam jumlah kasus kriminal maupun kejadian pencurian setiap tahun. Pada tahun 2018 angka kriminal meningkat pada Kecamatan Waru dengan 209 kasus sedangkan kasus pencurian 1449 kasus.

Hasil analisis juga menunjukkan dalam kurun waktu 2017 2018, rangking kriminal Kecamatan Waru selalu pada posisi tertinggi, selanjutnya Kecamatan Sidoarjo Kota mempertahankan posisi kedua dalam kurun waktu 2018.
Hasil kasus pencurian pun menunjukkan kecenderungan yang sama dengan variasi rangking yang sedikit berbeda. Rangking ini didasarkan pada urutan jumlah data yang ada pada setiap kecamatan dalam kurun waktu 2 tahun dari tahun 2017-2018.

Selanjutnya hasil kajian dilanjutkan dengan analisa pola spasial dengan GIS dari kasus kriminal dan angka pencurian dengan struktur Wilayah Penelitian berdasarkan Peraturan Daerah Nomor 6 tahun 2009 tentang Rencana Tata Ruang Wilayah Kabupaten Sidoarjo Tahun 2009-2029. Hasil analisis menunjukkan bahwa pada awal tahun 2017 sebagai titik waktu penelitian menunjukkan bahwa wilayah pusat kota di ORDE K1 SSWP 1 yaitu wilayah Kecamatan Waru, Kecamatan Gedangan dan Kecamatan Taman menjadi tempat konsentrasi tingkat kriminal dan pencurian sedangkan selanjutnya bergeser pada wilayah ORDE K1 SSWP 2 pada Kecamatan Sidoarjo, Kecamatan Buduran, dan Kecamatan Candi. Kemudian pada terlihat memiliki kecenderungan dalam peningkatan angka kriminal namun pada tahun 2018 pergeseran terjadi pada wilayah SSWP 4 dengan peningkatan signifikan.

Dari analisis pola spasial kriminal pencurian adalah teori difusi yaitu mencoba menelaah perjalaran atau pemekaran fenomena dalam ruang dan dimensi waktu tertentu dalam urban system.Tipe difusi antara lain:

1. Difusi Ekspansi (Expansion diffusion), yaitu suatu proses dimana informasi, material dan sebagainya menjalar melalui suatu populasi, dari suatu daerah ke daerah lain.

2. Difusi Penampungan (Relocation diffusion), merupakan proses yang sama dengan persebaran keruangan dimana informasi atau material yang didifusikan meninggalkan daerah yang lama dan berpindah atau ditampung di daerah yang baru.

3. Difusi Kaskade (Cascade diffusion) yaitu, proses penjalaran atau penyebaran fenomena melalui beberapa tingkat atau hierarki.

Kesimpulan dari analisis di atas adalah tipe Difusi Penampungan (Relocation diffusion), yang merupakan proses yang sama dengan persebaran keruangan dimana informasi atau material yang didifusikan meninggalkan daerah yang lama dan berpindah atau ditampung di daerah yang baru. Kesimpulan ini diambil dengan melihat perubahan pola aggregasi block kriminal pencurian pada tahun 2017 2018 di Wilayah Penelitian yang berpindah dari di wilayah Pusat Kota yaitu SSWP I di daerah Waru dan SSWP II di daerah Sidoarjo Kota.

Kesimpulan hasil analisis diatas dapat dilihat di bawah ini: 1) Faktor Ekologi Populasi Penduduk

Pada tahun 2017 pusat kepadatan pencurian berada pada wilayah pusat kota di SSWP II di Sidoarjo yang berpopulasi lebih rendah dari wilayah SSWP lain.

Pada tahun 2018 Pusat Kepadatan pencurian bergeser dari wilayah pusat kota di SSWP II di Sidoarjo yang berpopulasi lebih rendah ke wilayah SSWP I di Waru yang populasinya sedang berkembang.

\section{2) Faktor Ekologi Kepadatan Penduduk}

Pada tahun 2017 pusat kepadatan pencurian berada pada wilayah pusat kota di SSWP I di Waru yang kepadatannya lebih tinggi dari wilayah SSWP lain.

Pada tahun 2018 pusat kepadatan pencurian bergeser dari wilayah pusat kota di SSWP I di Waru yang kepadatannya 
Tabel 2.

Hasil uji korelasi pearson angka Kriminal pencurian dan faktor-faktor Ekologi kriminal wilayah penelitian tahun 2017-2018.

\begin{tabular}{ccccc}
\hline \hline No & $\begin{array}{c}\text { Faktor } \\
\text { Ekologi }\end{array}$ & $\begin{array}{c}\text { Pearson } \\
\text { Correlation }\end{array}$ & Kesimpulan & Uji hipotesis \\
\hline 1 & $\begin{array}{l}\text { populasi } \\
\text { penduduk } \\
\text { kepadatan } \\
\text { penduduk }\end{array}$ & 0.46 & sedang & Signifikan \\
2 & 0.34 & rendah & Tidak Signifikan \\
3 & $\begin{array}{l}\text { luas } \\
\text { permukiman }\end{array}$ & 0.91 & sangat kuat & Signifikan \\
4 & $\begin{array}{l}\text { luas wilayah } \\
\text { komersil }\end{array}$ & 0.80 & sangat kuat & Signifikan \\
5 & kemiskinan & 0.50 & sedang & Tidak Signifikan \\
6 & pengangguran & -0.17 & sangat rendah & Signifikan \\
\hline \hline
\end{tabular}

lebih tinggi ke wilayah SSWP II di Sidoarjo yang kepadatannya mulai naik.

3) Faktor Ekologi Luas Permukiman :

Pada tahun 2017 Pusat Kepadatan pencurian berada pada wilayah pusat kota di SSWP I di Waru yang luas permukimannya lebih kecil dari wilayah SSWP lain.

Pada tahun 2018 Pusat Kepadatan pencurian bergeser dari wilayah pusat kota SSWP I di Waru yang luas permukimannya lebih kecil ke wilayah SSWP II di Sidoarjo yang luas permukimannya lebih besar.

4) Faktor Ekologi Luas Komersil :

Pada tahun 2018 Pusat Kepadatan pencurian berada pada wilayah pusat kota di SSWP I di Waru yang luas wilayah komersilnya lebih besar dari wilayah SSWP lain.

\section{5) Faktor Ekologi Faktor Kemiskinan :}

Pada tahun 2018 pusat kepadatan pencurian berada pada wilayah pusat kota di SSWP I di Waru yang tingkat kemiskinannya tidak terlalu besar .

\section{6) Faktor Ekologi Kekumuhan}

Pada tahun 2018 pusat kepadatan pencurian berada pada wilayah pusat kota di SSWP II di Sidoarjo yang tingkat kekumuhannya besar.

\section{7) Faktor Pengangguran :}

Pada tahun 2018 Pusat Kepadatan pencurian berada pada wilayah pusat kota di SSWP I di Waru yang tingkat Penganggurannya rendah dari wilayah SSWP lain.

Hasil di atas diperoleh bahwa distribusi angka pencurian baik secara deskriptif maupun spasial juga teridentifikasi memiliki kecenderungan pola spasial tertentu berdasarkan faktor-faktor ekologi kriminal dan teridentifikasi polanya pada struktur ruang di dalam Wilayah Penelitian.

\section{Identifikasi Korelasi Kriminal Pencurian dan Faktor- faktor Ekologi Kriminal di Wilayah Penelitian}

Pada sub bab ini menyajikan hasil analisa uji korelasi dengan korelasi Pearson untuk mendapatkan hubungan antara variabel terikat dan variabel bebas penelitian serta menguji dengan uji t semua hipotesis penelitian ini. Hasil korelasi dapat Tabel 2.

Pada Uji Korelasi yang pertama antara variabel terikat Angka Pencurian dengan populasi penduduk diperoleh koefisien korelasinya adalah 0.455709 dengan tanda positif (+). Hasil ini dibandingkan dengan kriteria penilaian korelasi sehingga mendapatkan tingkat hubungan yang sedang di antara kedua faktor tersebut. Dari hasil ini menunjukkan bahwa apabila pertambahan pada jumlah populasi penduduk diikuti dengan pertambahan pada angka pencurian.

Pada Uji Korelasi yang kedua antara variabel terikat Angka Pencurian dengan kepadatan penduduk diperoleh koefisien korelasinya adalah 0.340759 dengan tanda positif (+). Hasil ini dibandingkan dengan kriteria penilaian korelasi sehingga mendapatkan tingkat hubungan yang rendah di antara kedua faktor tersebut. Dari hasil ini menunjukkan bahwa apabila pertambahan pada kepadatan penduduk diikuti dengan pertambahan pada angka pencurian.

Pada Uji Korelasi yang ketiga antara variabel terikat Angka Pencurian dengan luas wilayah permukiman diperoleh koefisien korelasinya adalah 0.906344 dengan tanda positif (+). Hasil ini dibandingkan dengan kriteria penilaian korelasi sehingga mendapatkan tingkat hubungan yang sangat kuat di antara kedua faktor tersebut. Dari hasil ini menunjukkan bahwa apabila pertambahan pada luas wilayah permukiman diikuti dengan pertambahan pada angka pencurian.

Pada Uji Korelasi yang keempat antara variabel terikat Angka Pencurian dengan luas wilayah komersil diperoleh koefisien korelasinya adalah 0.802745 dengan tanda positif (+). Hasil ini dibandingkan dengan kriteria penilaian korelasi sehingga mendapatkan tingkat hubungan yang sangat kuat di antara kedua faktor tersebut. Dari hasil ini menunjukkan bahwa apabila pertambahan pada luas wilayah komersil diikuti dengan pertambahan pada angka pencurian.

Pada Uji Korelasi yang kelima antara variabel terikat Angka Pencurian dengan kemiskinan diperoleh koefisien korelasinya adalah 0.500814 dengan tanda positif (+). Hasil ini dibandingkan dengan kriteria penilaian korelasi sehingga mendapatkan tingkat hubungan yang sedang di antara kedua faktor tersebut. Dari hasil ini menunjukkan bahwa apabila pertambahan pada kemiskinan diikuti dengan pertambahan pada angka pencurian.

Pada Uji Korelasi yang keenam antara variabel terikat Angka Pencurian dengan pengangguran diperoleh koefisien korelasinya adalah -0.17447 dengan tanda negatif (-). Hasil ini dibandingkan dengan kriteria penilaian korelasi sehingga mendapatkan tingkat hubungan yang sangat rendah di antara kedua faktor tersebut. Dari hasil ini menunjukkan bahwa apabila pertambahan pada kemiskinan diikuti dengan pertambahan pada angka pencurian.

Berikutnya nilai hasil uji t, nilai ini dapat digunakan untuk menguji hipotesis penelitian yakni: ada korelasi/hubungan signifikan kriminal pencurian dengan faktor-faktor ekologi kriminal, yang secara statistik dapat dituliskan sebagai berikut: Agar hipotesis di atas dapat dibuktikan, maka nilai t hitung dibandingkan dengan nilai t tabel, dengan ketentuan: Jika nilai $\mathrm{t}$ hitung $>\mathrm{t}$ tabel, maka $\mathrm{H} 0$ ditolak, dan jika nilai $\mathrm{t}$ hitung < t tabel, maka $\mathrm{HO}$ diterima.

- $\mathrm{H} 1 ; \mathrm{H} 0: \rho=0$ : artinya ada hubungan antara peningkatan factor angka kriminal pencurian dengan populasi penduduk dan jumlah kepadatan penduduk tiap kecamatan di Wilayah Penelitian.

- Ha: $\rho \neq 0$, artinya tidak ada hubungan antara peningkatan faktor angka kriminal pencurian dengan jumlah kepadatan penduduk dan populasi penduduk tiap kecamatan di Wilayah Penelitian. t Stat $=37.65926793$, t Critical twotail $=2.776445105$ Dengan demikian, karena nilat $\mathrm{t}$ hitung $>\mathrm{t}$ tabel, maka H0 diterima, sehingga kesimpulannya ada korelasi/hubungan signifikan angka criminal pencurian 
dengan populasi penduduk $\mathrm{t}$ Stat $=-4.88643$, $\mathrm{t}$ Critical two-tail $=2.776445105$ Dengan demikian, karena nilat $\mathrm{t}$ hitung $<\mathrm{t}$ tabel, maka Ha diterima, sehingga kesimpulannya tidak ada korelasi/hubungan signifikan angka kriminal pencurian dengan kepadatan penduduk.

- H2; H0: $\rho=0$ : ada hubungan antara peningkatan factor angka kriminal pencurian dengan peningkatan jumlah penduduk miskin. Ha: $\rho \neq 0$ : tidak ada hubungan antara peningkatan factor angka kriminal pencurian dengan peningkatan jumlah penduduk miskin. $\mathrm{t}$ Stat $=$ 2.796227614, t Critical two-tail $=2.776445105$. Dengan demikian, karena nilat $\mathrm{t}$ hitung $>\mathrm{t}$ tabel, maka $\mathrm{H} 0$ diterima, sehingga kesimpulannya ada korelasi/hubungan signifikan angka kriminal pencurian dengan jumlah penduduk miskin.

- H3, H0: $\rho=0$ : ada hubungan antara peningkatan faktor angka kriminal pencurian dengan luas wilayah permukiman di Wilayah Penelitian. Ha: $\rho \neq 0$ : tidak ada hubungan antara peningkatan factor angka kriminal pencurian dengan luas wilayah permukiman di Wilayah Penelitian. $\mathrm{t}$ Stat $=12.73250212, \mathrm{t}$ Critical two-tail $=$ 2.776445105. Dengan demikian, karena nilat t hitung $>t$ tabel, maka H0 diterima, sehingga kesimpulannya ada korelasi/hubungan signifikan angka kriminal pencurian dengan jumlah penduduk miskin.

- H4, H0: $\rho=0$ : ada hubungan antara peningkatan factor angka kriminal pencurian dengan luas wilayah komersil di Wilayah Penelitian. Ha: $\rho \neq 0$ : tidak ada hubungan antara peningkatan factor angka kriminal pencurian dengan luas wilayah komersil di Wilayah Penelitian. $\mathrm{t}$ Stat $=$ 4.715506005 , t Critical twotail $=2.776445105$ Dengan demikian, karena nilat thitung<ttabel, maka H0 ditolak, sehingga kesimpulannya tidak ada korelasi/hubungan signifikan angka criminal pencurian dengan jumlah penduduk miskin.

- H5, H0: $\rho=0$ : ada hubungan antara peningkatan factor angka kriminal pencurian dengan pengangguran di Wilayah Penelitian. Ha: $\rho \neq 0$ : tidak ada hubungan antara peningkatan factor angka kriminal pencurian dengan pengangguran di Wilayah Penelitian. $\mathrm{t}$ Stat $=$ 15.63748589, t Critical twotail $=2.776445105$ Dengan demikian, karena nilat thitung >ttabel, maka H0 diterima, sehingga kesimpulannya ada korelasi/hubungan signifikan angka criminal pencurian dengan pengangguran.

Kesimpulan dari hasil analisis sub bab ini adalah faktorfaktor ekologi kriminal yang berpengaruh sangat kuat dalam pola spasial kriminal pencurian di Wilayah Penelitian adalah luas permukiman dan luas wilayah komersil. Faktorfaktor ekologi lain korelasinya pada interval sangat rendah sampai sedang.

Seluruh hasil analisis dalam proses penelitian inidielaborasi untuk mendapatkan kesimpulan akhir yang akan menjawab berbagai sasaran dalam penelitian ini. Proses elaborasi membantu menjawab tujuan penelitian dan menjadi dasar dalam pemberian rekomendasi penelitian. Pada bagian awal disajikan data pola spasial kriminal pencurian berdasarkan berdasarkan distribusi faktor-faktor ekologi kriminal dengan output gambar-gambar model pola spasial yang terkait dengan struktur Wilayah Penelitian. Hasil elaborasi yang kedua adalah dengan menarasikan pola spasial dalam tabulasi dengan hasil korelasi Pearson faktor-faktor ekologi kriminal sebagai kesimpulan akhir.

\section{KESIMPULAN}

Adapun hasil akhir dalam penelitian ini adalah tipe Difusi Penampungan (Relocation diffusion), yang merupakan proses yang sama dengan persebaran keruangan dimana informasi atau material yang didifusikan meninggalkan daerah yang lama dan berpindah atau ditampung di daerah yang baru. Kesimpulan ini diambil dengan melihat perubahan pola aggregasi block kriminal pencurian pada tahun 2017-2018 di Wilayah Penelitian yang berpindah dari di wilayah Pusat Kota Kecamata Sidoarjo ke wilayah Kecamatan Waru.

Faktor-faktor ekologi kriminal yang berkorelasi kuat sebagai faktor pembentuk kriminal pencurian di Kabupaten Sidoarjo adalah luas permukiman dan luas kawasan komersil Sedangkan populasi, kepadatan dan kemiskinan penduduk berkorelasi rendah sampai sedang

\section{DAFTAR PUSTAKA}

[1] E. C. Hardiansah and D. Muttaqin, "Most Livable City Index: Pendekatan Baru dalam Mengukur Tingkat Kenyamanan Kota," Bulletin Tata Ruang, Jakarta, pp. 28-31, Jul-2011.

[2] R. E. Park, E. W. Burgess, and R. D. MacKenzie, The City. Chicago, Illinois: The University of Chicago Press, 1925.

[3] R. Stark, "Deviant places: A theory oh the ecology of crime," Criminology, vol. 25, no. 4, pp. 893-910, 1987.

[4] Sugiyono, Statistika Untuk Penelitian. Jakarta: Alfabeta, 2015.

[5] I. S. Susanto, Statistik Kriminal Sebagai Konstruksi Sosial. Jogjakarta: Genta Publishing, 2011. 